\title{
RADIOCARBON DATING OF MUMIYO FROM THE VESTFOLD HILLS, EAST ANTARCTICA
}

\author{
by Kevin Kiernan, Anne McConnell, Eric Colhoun and Ewan Lawson
}

(with one table and one text-figure)

Kiernan, K., McConnell, A., Colhoun, E. \& Lawson, E., 2002 (31:xii): Radiocarbon dating of mumiyo from the Vestfold Hills, East Antarctica. Papers and Proceedings of the Royal Society of Tasmania 136: 141-144. https://doi.org/10.26749/rstpp.136.141 ISSN 0080-4703. School of Geography and Environmental Studies, University of Tasmania, Private Bag 78, Hobart, Tasmania 7001, Australia (KK*, AMc); Department of Geography and Environmental Science, University of Newcastle, Callaghan, NSW 2308, Australia (EC); Australian Nuclear Science and Technology Organisation, PMB 1, Menai, NSW 2234, Australia (EL). *Author for correspondence.

Accelerator mass spectrometer (AMS) radiocarbon dating of mumiyo deposited by snow petrels at nesting sites in the Vestfold Hills indicates the colonies were established after $4800 \mathrm{yr}$ BP (uncorrected for marine reservoir effect). Sites on the highest hills were probably established first, but colonisation took place long after initial deglaciation, which was well advanced by $12.5 \mathrm{k}$ yr BP. The reason for late colonisation is not known. Perhaps older sites exist, but current evidence suggests the main colonisation occurred after the mid-Holocene re-advance of the Sørsdal Glacier. $\delta^{13} \mathrm{C}$ values indicate a diet of krill.

Key Words: Antarctica, Vestfold Hills, mumiyo, AMS radiocarbon dating, snow petrels.

\section{INTRODUCTION}

In Antarctica, mumiyo, a waxy accumulation of proventricular oil ejected by nesting snow petrels (Pagodroma nivea) (Warham et al. 1976), has been radiocarbon-dated to estimate the timing of the initial deglaciation of fringe areas of the continent and establishment of the snow petrel populations. Conventional radiocarbon dating of mumiyo from the Untersee Oasis of central Dronning Maud Land $\left(71^{\circ} \mathrm{S}, 13^{\circ} \mathrm{E}\right)$ recorded discontinuous petrel occupation since 34 kyr BP (Hiller et al. 1988); two samples from the Robertsoskollen nunatak group, northern Ahlmannryggen, Dronning Maud Land $\left(-71^{\circ} \mathrm{S}, 3^{\circ} \mathrm{E}\right)$, suggested that occupation began in about 7 kyr BP (Ryan et al. 1992) and in the Bunger Hills, Wilkes Land $\left(66^{\circ} 10^{\prime} \mathrm{S}, 101^{\circ} 45^{\prime} \mathrm{E}\right)$, occupation began before $10 \mathrm{kyr}$ BP (Verkulich \& Hiller 1994).

This paper reports accelerator mass spectrometer (AMS) radiocarbon dates from snow petrel nesting sites in the Vestfold Hills, East Antarctica (fig. 1). The Vestfold Hills oasis covers an area of about $413 \mathrm{~km}^{2}$ and has a maximum altitude of $158 \mathrm{~m}$. Four marine inlets, locally termed 'fjords', penetrate the hills deeply. The East Antarctic Ice Sheet bounds the hills on the east and the Sørsdal Glacier bounds them on the south. The extent to which the hills were submerged by the ice sheet and glacier during the Vestfold Glaciation - considered to represent the last glacial maximum - is debated (Adamson \& Pickard 1986, Fitzsimons 1991, Gore 1997). The age of deglaciation is minimally constrained by cosmogenic isotope exposureage dating of subglacial erratics within $1-2 \mathrm{~km}$ of the ice sheet's margin that indicated almost complete deglaciation by $12.5 \pm 1.6 \mathrm{kyr}$ BP (Fabel et al. 1997). Fitzsimons \& Domack (1993) showed that the southern hills had been transgressed by the sea by $9 \mathrm{kyr} \mathrm{BP}$, and that re-advance of the Sørsdal Glacier eroded the marine sediments between 9 and 0.7 kyr BP. Adamson \& Pickard (1986) suggested that this re-advance occurred between 3 and $1.5 \mathrm{kyr}$ BP.

\section{METHOD}

Mumiyo deposits were obtained by Kevin Kiernan and Anne McConnell during the 1996-97 austral summer with logistical support provided by the Australian Antarctic Division. Field sampling aimed at obtaining the oldest mumiyo deposits. Only basal samples were taken from most accumulations, though at a few sites with thick deposits, additional samples were taken at different levels in the sequence. Care was taken not to disturb nesting birds. The altitudes of the sample sites were recorded (table 1). Few sites had deposits more than 10-20 mm thick. The basal $2 \mathrm{~mm}$ were carefully scraped from the deposit to avoid clastic impurities that might contain old carbon. The samples were wrapped in aluminium foil and plastic bags, and refrigerated for transport to Lucas Heights for analysis. The $\delta^{13} \mathrm{C}$ content, per cent modern carbon and conventional radiocarbon age were determined by Ewan Lawson using the ANTARES accelerator mass spectrometer facility at the Australian Nuclear Science and Technology Organisation laboratories at Lucas Heights, NSW, Australia.

\section{RESULTS}

The radiocarbon ages obtained from the basal mumiyo samples, uncorrected for marine reservoir effect, range from $4800 \pm 60 \mathrm{yr} \mathrm{BP}(\mathrm{OZD} 192)$ to $500 \pm 140 \mathrm{yr} \mathrm{BP}(\mathrm{OZD} 190)$ (table 1). Radiocarbon measurements of modern marine samples from Antarctica have given ages of 830-1460 yr BP, with a mean of $1180 \mathrm{yr}$ BP (Stuiver et al. 1986, Hiller et al. 1988, Gordon \& Harkness 1992, Ryan et al. 1992). Modern samples of marine algae and shells from the Vestfold Hills have given ages of 950-1310 yr BP (Adamson \& Pickard $1983,1986)$. Using a value of $1300 \mathrm{yr} \mathrm{BP}$ for the marine reservoir effect would make the sample from Boulder Hill (OZD 185) close to modern and the sample from Inner Long Peninsula of $500 \pm 140$ (OZD 190) yet to be deposited. As the appropriate correction factor is uncertain, none has been applied here because to do so would introduce further uncertainty in the age estimates. The earliest dates indicate 


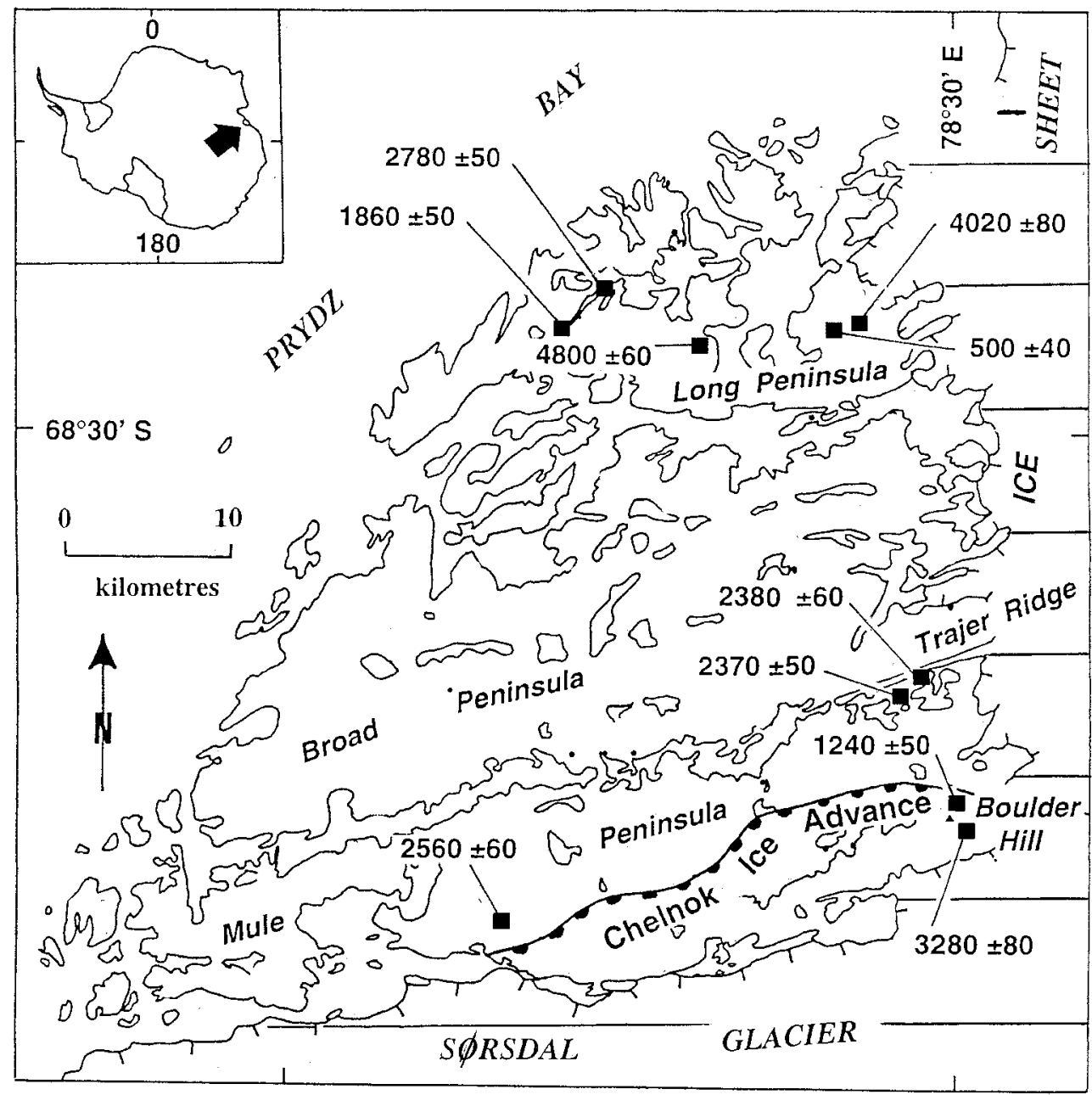

FIG. 1 - Location of dated mumiyo samples from the Vestfold Hills, East Antarctica.

TABLE 1

Location and age of mumiyo samples from the Vestfold Hills

\begin{tabular}{lccccc}
\hline Site & $\begin{array}{c}\text { Sample } \\
\text { no. }\end{array}$ & $\begin{array}{c}\text { Altitude } \\
\text { (metres) }\end{array}$ & $\begin{array}{c}\text { Mumiyo } \\
\text { thickness } \\
(\mathrm{mm})\end{array}$ & $\begin{array}{c}\delta 13 \mathrm{C} \\
(\%)\end{array}$ & $\begin{array}{c}14 \mathrm{C} \text { age } \\
\text { (years, } \\
\text { uncorrected) }\end{array}$ \\
\hline Boulder Hill & OZD185 & 110 & 150 & -28.62 & $1240 \pm 50$ \\
Boulder Hill & OZD186 & 80 & 140 & $-29.00 *$ & $3280 \pm 80$ \\
Trajer Ridge & OZD187 & 80 & 100 & -29.80 & $2380 \pm 60$ \\
Trajer Ridge & OZD188 & 70 & 140 & -30.18 & $2370 \pm 50$ \\
Inner Long Peninsula & OZD189 & 140 & $<10$ & -29.94 & $4020 \pm 80$ \\
Inner Long Peninsula & OZD190 & 70 & 180 & -30.95 & $500 \pm 140$ \\
Outer Long Peninsula & OZD191 & 40 & $<50$ & -28.25 & $1860 \pm 50$ \\
Outer Long Peninsula & OZD192 & 75 & $<50$ & -29.58 & $4800 \pm 60$ \\
Outer Long Peninsula & OZD193 & 30 & $<50$ & -30.22 & $2780 \pm 50$ \\
Poseidon Plain & OZD194 & 20 & 70 & -29.99 & $2560 \pm 60$ \\
\hline
\end{tabular}

* assumed value 
that the Vestfold Hills were probably colonised by snow petrels only as recently as 4800 (uncorrected) years ago and at least 8000 years after the initial deglaciation.

Since only 10 samples have been dated, the age of colonisation may be underestimated. However, as six of the samples were collected within $2-3 \mathrm{~km}$ of the ice sheet, the colonisation was probably widespread by $3500 \mathrm{yr}$ BP. There is little pattern in the age distribution of the petrel sites, except that those on high points may be slightly older than those in adjacent low areas, although the reverse occurs at Boulder Hill.

Rates of mumiyo accumulation range from $0.002 \mathrm{~mm} /$ yr (OZD 189) to $0.360 \mathrm{~mm} / \mathrm{yr}$ (OZD 190). The thickest accumulation of mumiyo recorded during this survey was deposited in only 500 years. The rate of accumulation at a site appears to be independent of the basal age of the sample. This suggests that occupation of nesting sites may have been discontinuous in the long term. However, accumulation of $180 \mathrm{~mm}$ in only 500 years at Vestfold Hills, giving an average of $0.360 \mathrm{~mm} / \mathrm{yr}$, is a much faster rate than any recorded at Bunger Hills (Verkulich \& Hiller 1994) or at Robertsoskollen nunataks (Ryan et al. 1992).

\section{DISCUSSION}

The establishment of snow petrel colonies at Vestfold Hills appears to be much later than at other coastal nunataks and oases of East Antarctica. To what extent the ages of $34 \mathrm{kyr}$ $\mathrm{BP}$ in the Untersee Oasis (Hiller et al. 1988) and the $>10 \mathrm{kyr}$ BP of the Bunger Hills (Verkulich \& Hiller 1994) reflect absence of ice in these areas during the last glacial maximum is difficult to ascertain. At Bunger Hills, intensive colonisation occurred between 8 and 6 kyr BP and after 2 kyr BP. Only the latter phase appears to be temporally related to the late Holocene establishment of snow petrels at Vestfold Hills.

There is considerable evidence in coastal East Antarctica of advancing outlet glaciers during the mid-Holocene. From studies of the Mertz-Ninnis Trough, Dumont d'Urville Trough and Amery Depression, Domack et al. (1991), showed that grounding-line advance of outlet glaciers led to deposition of terrigenous sediment on the continental shelf between 7 and 4 kyr BP. Marine biogenic sediments overlie these deposits. They also showed that in Prydz Bay, to the west of Vestfold Hills, open marine conditions existed between 10.7 and 7.3 kyr BP.

A widespread advance of the East Antarctic Ice Sheet margin on the Wilkes Coast during the mid-late Holocene was attributed by Goodwin $(1996,1998)$ to ice thickening in central-East Antarctica due to $50 \%$ higher precipitation in the Holocene than during the last glacial maximum and to slow ice sheet flow response rates. This increased ice volumes in the coastal zone between 4 and $2.5 \mathrm{k}$ yr BP. Modelling suggests that a temperature increase of $5^{\circ} \mathrm{C}$ is required to cause the ice sheet to recede (Huybrechts \& Oerlemans 1990). Ice-core data suggest that temperatures were $0.5^{\circ} \mathrm{C}$ warmer around $4 \mathrm{k}$ yr BP. Cooling occurred from $2 \mathrm{kyr}$ to $1 \mathrm{kyr} B P$ when there was brief warming before the Little Ice Age. Temperatures during the Little Ice Age were about $0.5^{\circ} \mathrm{C}$ colder than present (Ciaias et al. 1994, Mayewski et al. 1995, Morgan et al. 1997).

Adamson \& Pickard (1986), and Fitzsimons \& Domack (1993) showed that the Sørsdal outlet glacier had advanced again recently in the southern part of the Vestfold Hills.
Adamson \& Pickard (1986) suggested that this Chelnok Advance occurred between 3 and $1.5 \mathrm{kyr}$ BP. As Boulder Hill lies within this ice limit, the older date for mumiyo of $3280 \pm 80$ yr BP (uncorrected) is broadly consistent with their estimate. Fitzsimons \& Domack (1993) showed that slabs of sheared ice formed the cores of the sediment masses associated with moraine of the Chelnok ice advance, and that the ice limit may have been attained as recently as 710 yr BP (corrected age).

Collectively, this evidence supports the hypothesis that re-advance of outlet glaciers in the peripheral zone of East Antarctica during the mid-late Holocene was associated with climatic conditions less favourable for snow petrels than in the subsequent three or four millenia. Snow petrels apparently colonised the Vestfold Hills during the milder conditions following the last advance of outlet glaciers in coastal East Antarctica. The inferred climatic evidence suggests that average temperatures did not change by more than about $1^{\circ} \mathrm{C}$ during this period.

The late Holocene colonisation by snow petrels at Vestfold Hills bears comparison with evidence of abandoned penguin rookeries in East Antarctica. Adélie penguins were abundant on the Victoria Land coast between 4 and $3 \mathrm{kyr}$ BP, probably due to abundant open water and reduced snow cover. Many colonies were abandoned $-3 \mathrm{kyr}$ BP, but were re-established about 1.4-0.8 kyr BP (Baroni \& Orombelli 1994). Similarly, abandoned rookeries in the Windmill Islands were occupied from 4-3 kyr BP (Goodwin 1998). The open water conditions that facilitated the establishment of penguin rookeries are likely to have been associated with higher air and sea-surface temperatures that promoted greater coastal precipitation (Goodwin 1998). Sea-surface temperatures interpreted from stable oxygen isotope ratios of calcareous marine fauna and diatom transfer functions suggest sea-surface temperatures were $0.5-1.0^{\circ} \mathrm{C}$ warmer than now at 4 kyr BP (Pichon et al. 1992, Goodwin 1998). However, unlike Adélie penguins, snow petrels are not reliant on near-shore food sources. Hence, reduced open water inshore is less likely to affect the viability of colonies than is greater snowfall during warm periods, notwithstanding enhanced summer melt.

The $\delta^{13} \mathrm{C}$ values of mumiyo offer some insight into the likely foods available to snow petrels. Ryan et al. (1992) suggested that $\delta^{13} \mathrm{C}$ values for tissues from animals that feed on Antarctic fish are likely to be $-24.5 \%$ or -26 to $-27 \%$ if the diet consists of Antarctic krill. The $\delta^{13} \mathrm{C}$ values reported for mumiyo range from -29 to $-31.1 \%$. Mean values determined from snow petrel body tissue are $-28 \%$ o (Ryan et al 1992, Verkulich \& Hiller 1994). The values obtained from Vestfold Hills mumiyo range from $-28.25 \%$ to $-30.95 \%$, which is closer to the figures suggesting a diet of krill than of fish.

\section{ACKNOWLEDGEMENTS}

We gratefully acknowledge field support provided by the Australian Antarctic Division. We thank Peter Corcoran, Pene Grete, Kevin Harlan and Ilse Kiessling for assistance in the field, and Steve Richards, Dennis Branch and Buck Rodger for logistic support. Michelle Leishman and Damian Gore provided information on some colony locations. We also thank Damian Gore and Peter McIntosh for comments on an earlier draft. The field program was supported by a 
grant from the Antarctic Science Advisory Committee. The AMS radiocarbon dating was made possible by an AINSE grant.

\section{REFERENCES}

Adamson, D.A. \& Pickard, J., 1983: Late Quaternary ice movement across the Vestfold Hills, East Antarctica. In Oliver, R.L., James, P.R. \& Jago, J.B. (Eds): Antarctic Earth Science, Australian Academy of Science, Canberra: 465-469.

Adamson, D.A. \& Pickard, J., 1986: Cainozoic history of the Vestfold Hills. In Pickard, J. (Ed.): Antarctic Oasis, Academic Press, Sydney: 63-97.

Baroni, C. \& Orombelli, G., 1994: Abandoned penguin rookeries as Holocene palaeoclimatic indicators in Antarctica. Geology 22: 23-26.

Ctais, P., Petit, J.R., Jouzel, J., Lorius, C., Barkov, N.I., Lipenkov, V. \& Nicolaitev, V., 1992: Evidence for an early Holocene climatic optimum in the Antarctic deep ice-core record. Climate Dynamics 6: 169-177.

DOMACK, E.W., Jull, A.J.T. \& NAKAO, S., 1991: Advance of East Antarctic outlet glaciers during the Hypsithermal: Implications for the volume state of the Antarctic ice sheet under global warming. Geology 19: 1059-1062.

Fabel, D., Stone, J., Fifield, L.K. \& Cresswell, R.G., 1997: Deglaciation of the Vestfold Hills, East Antarctica: Preliminary evidence from exposure dating of three subglacial arratics. In Ricci, C.A. (Ed.): The Antarctic Region: Geological Evolution and Processes, Terra Antarctica, Siena: 829-834.

Fitzsimons, S.J., 1991: Geomorphic development of the Vestfold Hills: Questions regarding Holocene deglaciation. In Gillieson, D.S. \& Fitzsimons, S. (Eds): Quaternary Research in Australian Antarcica: Future Directions. Spec. Publ. 3, Dept. Geography and Oceanography, University College, Australian Defence Force Academy, Canberra: $25-35$.

Fitzsimons, S.J. \& DOMACK, E.W., 1993: Evidence for Early Holocene deglaciation of the Vestfold Hills, east Antarctica. Polar Record 29: 237-240.

Goodwin, I.D., 1996: A mid to late Holocene readvance of the Law Dome ice margin, Budd Coast, East Antarctica. Antarctic. Science. 8(4): 395-406.

Goodwin, I.D., 1998: Did changes in Antarctic ice volume influence Late Holocene sea-level lowering? Quaternary Science Reviews 17: 319-332.
Gordon, J.E. \& Harkness, D.D., 1992: Magnitude and geographic variations of the radiocarbon content in antarctic marine life: Implications for reservoir cor rections in radiocarbon dating. Quaternary Science Reviews 11: $697-708$.

Gore, D.B., 1997: Last Glaciation of Vestfold Hills: extension of the East Antarctic ice sheet or lateral expansion of Sørsdal Glacier? Polar Record 33(184): 5-12.

Hiller, A., Wand, U., Kafmpr, H. \& Stackebrandt, W., 1988: Occupation of the Antarctic continent by petrels during the past 35000 years: inferences from a carbon-14 study of stomach oil deposits. Polar Biology 9: 69-77.

Huybrechts, T. \& Oerlemans, J., 1990: Response of the Antarctic ice sheet to future greenhouse warming. Climate Dynamics 5: 93-102.

Mayewski, P.A., Lyons, W.B., Zielinski, G., Twickler, M., Whitlow, S., Dibb, J., Grootes, P., Taylor, K., Whung, P-Y., Fosberry, L., WaKe, C. \& Welch, K., 1995: An ice-core-based, Late Holocene history for the Transantarctic Mountains, Antarctica. Antarctic Research Series, 67. Contributions to Antarctic Research IV, American Geophysical Union: 33-45.

Morgnn, V.I., WOOKEY, C.W., LI, J., VAN OMmen, T.D., SkINNER, W. \& FitzPATRICK, M.F., 1997: Site information and initial results from deep drilling on Law Dome, Antarctica. Journal of Glaciology 43: 3-10.

Pichon, J-J., Labeyrie, L.D., Bareille, G., Labracherie, M., DOPRAT, J. \& JOUZEL, J., 1992: Surface water temperature changes in the high latitudes of the Southern Hemisphere over the last glacial-interglacial cycle. Palaeoceanography 7: 289-318.

Ryan, P. G., Steele, W.K., Siegfried, W.R. \& Vogel, J.C., 1992: Radiocarbon dates of snow petrel regurgitations can reveal exposure periods for nunataks in Antarctica. South African Journal of Science 88: 578-580.

Stuiver, M., Pearson, G.W. \& Brazuinas, T., 1986: Radiocarbon age calibration of marine samples back to $9000 \mathrm{cal} \mathrm{yr}$ BP. Radiocarbon 28: 980-1021.

Verkulich, S.R. \& Hiller, A., 1994: Holocene deglaciation of the Bunger Hills revealed by $14 \mathrm{C}$ measurements on stomach oil deposits in snow petrel colonies. Antarctic Science 6(3): 395-399.

WARHAM, J., WATTS, R. \& DAINTY, R.J., 1976: The composition, energy content and function of the stomach oils of petrels (Order, Procellariiformes). Journal of Exploratory Marine Biology and Ecology. 23: 1-13.

(accepted 9 December 2002) 